\title{
Description of a new species of Tatia from rio Tocantins drainage, central Brazil, with notes on Tatia simplex Mees, ə 1974 (Siluriformes, Auchenipteridae)
}

Correspondence:

Luisa M. Sarmento-Soares sarmento.soares@gmail.com

Submitted September 21, 2019

Accepted December 10, 2019

by Fernando Carvalho

Published April 20, 2020
${ }^{\circ}$ Jordson de Souza e Souza ${ }^{1},{ }^{\circ}$ Luisa M. Sarmento-Soares ${ }^{2,3},{ }^{\circ}$ André L. Colares Canto ${ }^{4}$ and ${ }^{\oplus}$ Frank Raynner V. Ribeiro ${ }^{1,4}$

Tatia comprises twenty-five valid species, distributed in the main inland watersheds of South America, including the Orinoco, Essequibo, and coastal rivers of Suriname, Amazon, upper rio Paraná and São Francisco basins. A new species is described from tributaries of upper rio Manuel Alves on uplands of Serra Geral do Tocantins plateau, Tocantins State, Brazil. It is promptly distinguished from all congeners, except Tatia britskii, due to absence of an adipose fin. It differs from $T$. britskii by the longer caudal peduncle length $(24.1-30.5 \%$ SL, mean 25.3 vs. 20.0-22.7, mean 20.9); caudal peduncle depth (10.9-16.8 SL, mean 14.1 vs. 9.4-10.5, mean 9.8), and anterior cranial border with mesethmoid width equals its length ( $v s$. width approximately three times its length in $T$. britskii). Additionally, information regarding the poorly known species Tatia simplex originally described from rio das Mortes, is provided.

Keywords: Neotropical, Ostariophysi, South America, Systematics, Taxonomy.
Online version ISSN 1982-0224

Print version ISSN 1679-6225

Neotrop. Ichthyol.

vol. 18, no. 1, Maringá 2020

Epub, Apr 17, 2020
1 Programa de Pós-Graduação em Recursos Aquáticos Continentais Amazônicos, Instituto de Ciências e Tecnologia das Águas, Universidade Federal do Oeste do Pará. Avenida Mendonça Furtado, 2946, 68040-470 Santarém, PA, Brazil. (JSS) jordsonssouza@gmail.com, (FRVR) fraynner@yahoo.com.br

2 Programa de Pós-Graduação em Biologia Animal, Universidade Federal do Espírito Santo. Prédio da Biologia, Câmpus de Goiabeiras, 29043-900 Vitória, ES, Brazil. sarmento.soares@gmail.com

3 Laboratório de Ecologia e evolução de Peixes, Universidade Estadual de Feira de Santana. Avenida Transnordestina s/n - Novo Horizonte, 44036-900 Feira de Santana, BA, Brazil.

4 Instituto de Ciências e Tecnologia das Águas, Universidade Federal do Oeste do Pará, Avenida Mendonça Furtado, 2946, 68040470 Santarém, PA, Brazil. (ALCC) cantoandre@gmail.com 
Tatia abriga vinte e cinco espécies válidas distribuídas nos maiores sistemas fluviais de águas interiores da América do Sul, como o Orinoco, Essequibo, e rios costeiros do Suriname, Amazonas, alto Paraná e São Francisco. Uma espécie nova é descrita para tributários do alto rio Manuel Alves, nos contrafortes da Serra Geral do Tocantins, estado do Tocantins, Brasil. A espécie nova é facilmente distinguida de todos os congêneres, exceto Tatia britskii, pela ausência de nadadeira adiposa. Difere de T. britskii pelo maior comprimento do pedúnculo caudal (24,1-30,5\% CP, média 25,3 vs. $20,0-22,7 \%$ CP, média 20,9$)$; altura do pedúnculo caudal (10,9-16,8 SL, mean 14,1 vs. 9,4-10,5, mean 9,8) e margem craniana anterior com largura do mesetmoide igual a seu comprimento (vs. largura aproximadamente três vezes no seu comprimento em T. britskii). Adicionalmente, são fornecidas informações sobre Tatia simplex, uma espécie pouco conhecida, descrita para o rio das Mortes.

Palavras-chave: América do Sul, Neotropical, Ostariophysi, Sistemática, Taxonomia.

\section{INTRODUCTION}

Tatia Miranda Ribeiro, 1911 is currently the most species-rich genus in Centromochlinae, comprising twenty-five valid species of small-sized catfish present in all inland South American large drainages east of the Andes, as the Orinoco basin in Venezuela and Colombia, Amazon basin from Ecuador to Brazil, coastal rivers of northern South America between the mouths of the Orinoco and Amazon rivers and upper rio Paraná and São Francisco basins (Soares-Porto, 1998; Ferraris, 2003, 2007; Sarmento-Soares, Buckup, 2005; Akama, Sarmento-Soares, 2007; Sarmento-Soares, Birindelli, 2015; Calegari et al., 2019). The monophyly of the genus is supported by 13 molecular and three non-exclusive morphological synapomorphies: coronomeckelian bone obliquely positioned, hyomandibula and metapterygoid separated from each other, and contralateral anteromedial processes of basipterygium sutured to each other on anterior portion (Calegari et al., 2019).

In the rio Tocantins drainage, Tatia is represented by two species, namely: $T$. intermedia (Steindachner, 1877) and T. simplex Mees, 1974 (Ferraris, 2007; SarmentoSoares, Martins-Pinheiro, 2008). Tatia simplex is poorly understood taxonomically. Its description was based on a single juvenile specimen (28.5 mm SL) collected in 1968 at rio das Mortes, Mato Grosso State, Brazil. Since its original description by Mees (1974) the species was kept under the name Centromochlus simplex in taxonomic lists and catalogues, with geographic distribution reported only to the type locality (e.g., Ferraris, 2003, 2007). No additional material of the species was identified for thirty years, until the generic revision of Tatia by Sarmento-Soares, Martins-Pinheiro (2008). Although keept as incertae sedis in Centromochlinae (Sarmento-Soares, Martins-Pinheiro, 2008: Tab. 1), Tatia simplex appears as a valid Tatia species in recent contribution (Calegari et al., 2019). 
In this study, a new species of Tatia from the upper rio Tocantins is described and the identity and geographic distribution of $T$. simplex is revised.

\section{MATERIAL AND METHODS}

Osteological preparations were cleared and stained (CS) for cartilage and bone using the method of Taylor, Van Dyke (1985). Osteological data were obtained from radiographs for species poorly represented in ichthyological collections. Specimens examined as radiographs are noted as "Rx" in the Comparative Material section. Osteological nomenclature follows the Teleost Anatomy Ontology (Dahdul et al., 2010), with exceptions based on Birindelli (2014). Orientation of dentations on pectoral-fin spine as in Vanscoy et al. (2015). Drawings of cleared and stained specimens were rendered by camera lucida. Photographs of structural details were taken using a digital camera coupled to a Leica stereomicroscope. Species comparisons in diagnosis were provided based on direct examination of specimens, all mentioned in comparative material section.

Counts and measurements were made on the left side of the specimens whenever possible. All measurements are expressed as percents of standard length (SL), except subunits of the head, which are expressed as percents of head length (HL). Straight-line measurements were taken with a digital dial caliper, to the nearest $0.1 \mathrm{~mm}$. Measurements and counts follow Sarmento-Soares, Martins-Pinheiro (2008). Counts of fin rays and bony elements were obtained from alcohol preserved and CS specimens. Fin ray counts include anteriormost spine (capital Roman numeral) or unbranched ray (lower case Roman numeral) and all subsequent branched rays (Arabic numeral). Caudal-fin ray counts included all principal rays (i.e. all inner branched rays and the first unbranched ray of the dorsal and ventral lobes, also referred to as outer principal rays). Gill rakers of the anterolateral row were counted on the first branchial arch (ceratobranchial+ epibranchial). Branchiostegal rays and procurrent caudal-fin rays were taken from cleared and stained specimens. Vertebral counts include the five elements incorporated into the Weberian complex plus one terminal element associated with the hypural complex (following Vari, Ferraris, 2013). Vertebral counts were taken from cleared and stained specimens or radiographs. Standard length (SL) is expressed in $\mathrm{mm}$ and all other measurements are expressed as percentage of the SL, except subunits of the head, which are expressed as percentage of the head length.

Institutional abbreviations follows Sabaj Pérez (2010), with the exception of: Instituto Nacional da Mata Atlântica [formely Museu de Biologia Professor Mello Leitão], Santa Teresa (MBML); Coleção Ictiológica do Núcleo de Pesquisas em Limnologia, Ictiologia e Aquicultura, Universidade Estadual de Maringá, Maringá (NUP); Ichthyological collection, Universidade Federal do Oeste do Pará, Santarém (UFOPA-I). In the list of comparative material examined, the museum abbreviation and catalog number are followed by the total number of specimens in that lot, range of standard length, cleared and stained (CS) or radiograph (Rx), and abbreviated collection data. 


\section{RESULTS}

\section{Tatia akroa, new species}

urn:lsid:zoobank.org:act:4ECA989 8-25FD-417D-90F8-4C757A37C2A0

(Fig. 1, Tab. 1)

Holotype. UFOPA-I 671, 38.4 mm SL, Brazil, Tocantins State, rio Tocantins basin, rio Perdida, 9¹1'23.44'’S 47¹5'59.14'’W, 30 May 2013, L. Brito.

Paratypes. MZUSP 82349, 14, 2 CS, 27.3-35.4 mm SL, rio Palma, near village of Taipas, on road Dianópolis-Conceição do Tocantins, Dianópolis, 23 Nov 2002, C. R. Moreira, J. C. Nolasco. UFOPA-I 670, 1, CS, $34.26 \mathrm{~mm} \mathrm{SL}$, collected with the holotype.

Diagnosis: Tatia akroa differs from its congeners, except T. britskii, by the absence of adipose fin ( $v s$. present). Differs from T. britskii by the caudal peduncle length (24.1$30.5 \%$ SL, mean 25.3 vs. 20.0-22.7\%, mean 20.9); caudal peduncle depth (10.9-16.8\% SL, mean 14.1 vs. 9.4-10.5\%, mean 9.8); mesethmoid broad in the new species, smallest width approximately equal to its length, whereas slender in T. britskii (smallest width approximately three times length see Sarmento-Soares, Birindelli, 2014: fig. 2). Further differs from $T$. simplex by the posterior margin of dorsal-fin spine smooth ( $v s$. with 1 to 3 distal denticulations). Further differs from Tatia aulopygia Kner, 1857, Tatia brunnea Mees, 1974, T. caxiuanensis Sarmento-Soares, Martins-Pinheiro, 2008, Tatia dunni (Fowler, 1945), Tatia galaxias Mees, 1974, Tatia gyrina (Eigenmann, Allen, 1942), Tatia jaracatia Pavanelli, Bifi, 2009, Tatia intermedia, T. meesi Sarmento-Soares, Martins Pinheiro, 2008, T. neivai (Ihering, 1930), and Tatia strigata Soares-Porto, 1995 by the cranial roof with two nuchal plates ( $v s$. cranial roof with three nuchal plates, anterior one smallest, somewhat rounded) and by dotted color pattern on sides of body ( $v s$. color pattern spotted or reticulated on flanks). Additionally distinct from Tatia bockmanni (Sarmento-Soares, Buckup, 2005), Tatia concolor Mees, 1974, Tatia marthae Vari, Ferraris, 2013, Tatia punctata Mees, 1974 by coracoid process somewhat large, about same length as pectoral-fin base (vs. coracoid process small, comparatively shorter than pectoral fin base). Further differs from Tatia boemia Koch, Reis, 1996, Tatia caudosignata DoNascimiento, Albornoz-Garzón, García-Melo, 2019, and T. nigra Sarmento-Soares, Martins-Pinheiro, 2008, by the number of post-Weberian vertebrae, 30 ( $v s$. between 32 to 36 vertebrae). From Tatia reticulata Mees, 1974, by posterior margin of dorsal spine with small denticulations, less than half in the width of spine axis (vs. well-formed retrorse denticulations, about same width as spine axis). From Tatia melanoleuca Vari, Calegari, 2014, Tatia musaica Royero, 1992, Tatia orca (Sarmento-Soares, Lazzarotto, Rapp Py-Daniel, Leitão, 2017), by small number of posterior denticulations, 11-15 (vs. large number of posterior denticulations on pectoral-spine, more than 20).

Description. Morphometric data presented in Tab. 1. Small size, examined adult specimens 38.3-49.3 mm SL. Body short, head slightly depressed anteriorly, progressively more elevated posteriorly. In dorsal view, profile of head longer than 

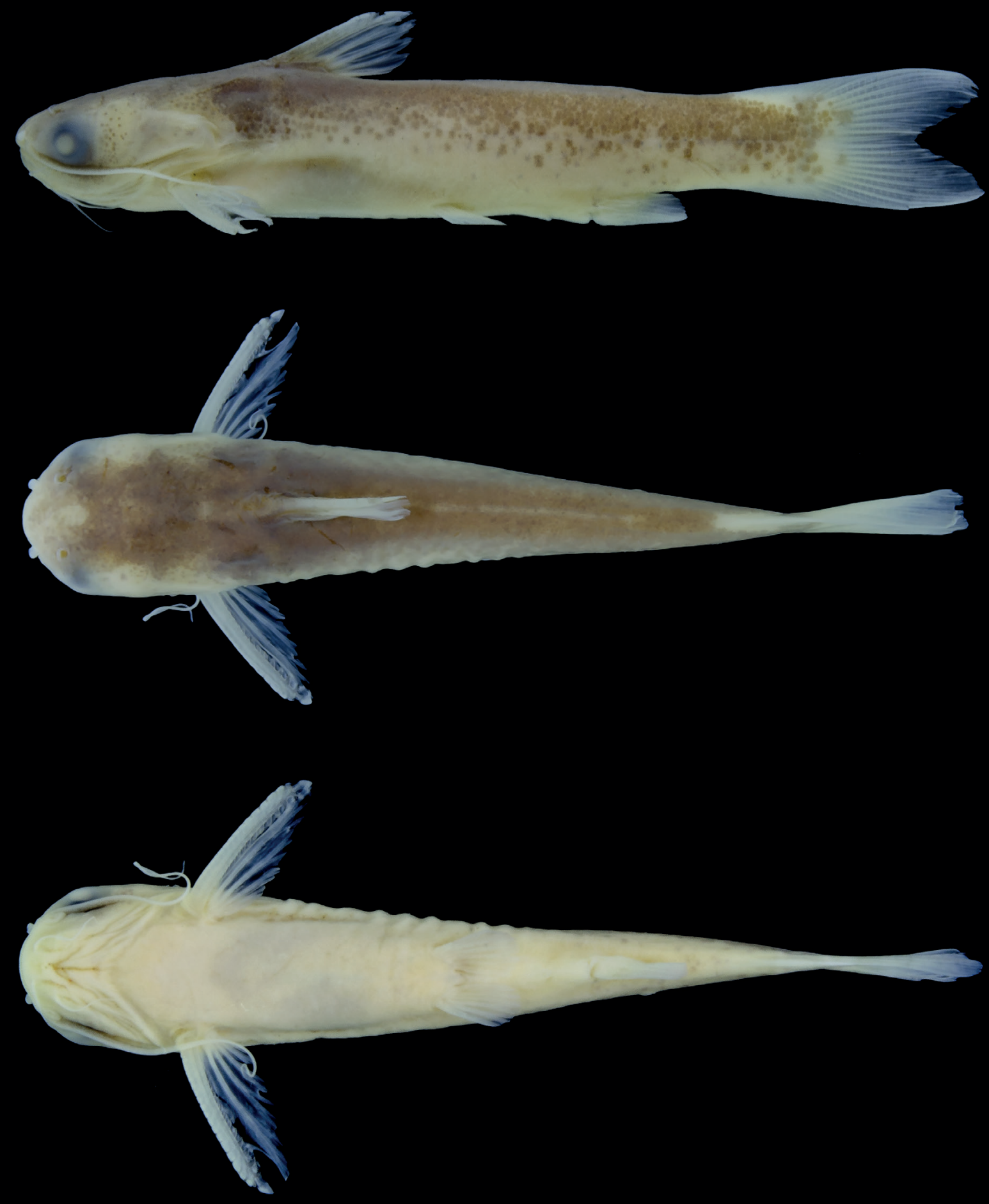

FIGURE 1 I Tatia akroa, lateral, dorsal and ventral views. UFOPA-I 671, holotype, male, $38.8 \mathrm{~mm}$ SL, rio Perdida, tributary of rio Sono, rio Tocantins basin, Tocantins State, Brazil. 
TABLE 1 I Morphometric data of holotype and 16 paratypes of Tatia akroa. Holotype included in the ranges and means. SD = Standard Deviation.

\begin{tabular}{|c|c|c|c|c|}
\hline & Holotype & Range & Mean & SD \\
\hline Standard length (mm) & 33.2 & $27.2-35.5$ & 31.2 & - \\
\hline \multicolumn{5}{|l|}{ Percents of standard length } \\
\hline Body depth & 18.2 & $18.2-22.1$ & 20.0 & 1.1 \\
\hline Body width & 19.7 & $19.3-22.0$ & 20.6 & 0.8 \\
\hline Caudal peduncle depth & 12.3 & $10.8-16.8$ & 14.1 & 1.3 \\
\hline Caudal peduncle length & 30.5 & $24.1-30.5$ & 25.3 & 2.0 \\
\hline Predorsal length & 43.3 & $31.2-43.3$ & 34.0 & 3.5 \\
\hline Preanal length & 74.3 & $62.9-76.6$ & 70.5 & 2.9 \\
\hline Prepelvic length & 58.3 & $51.2-63.2$ & 56.2 & 3.1 \\
\hline Dorsal origin to pectoral origin & 7.0 & $7.0-12.2$ & 9.7 & 1.1 \\
\hline Dorsal origin to pelvic origin & 20.2 & $20.2-26.1$ & 23.7 & 1.7 \\
\hline Pectoral origin to pelvic origin & 32.0 & $30.9-40.6$ & 34.1 & 2.4 \\
\hline Prepectoral length & 25.2 & $21.4-28.9$ & 23.9 & 1.9 \\
\hline Dorsal-fin base length & 11.8 & $10.5-12.7$ & 11.4 & 0.7 \\
\hline Anal-fin base length & 10.3 & $8.8-13.2$ & 11.1 & 1.3 \\
\hline Dorsal fin spine length & 13.7 & $12.3-17.3$ & 14.7 & 1.2 \\
\hline Pectoral fin spine length & 28.1 & $20.3-28.2$ & 24.0 & 2.3 \\
\hline Humeral spine lenght & 17.0 & $13.6-18.9$ & 17.0 & 1.2 \\
\hline Longest pelvic fin ray & 10.0 & $8.5-11.3$ & 9.9 & 0.7 \\
\hline Maxillary barbel length & 38.3 & $31.1-43.6$ & 37.8 & 3.6 \\
\hline Outer mental barbel length & 10.2 & $8.1-12.5$ & 10.1 & 1.3 \\
\hline Inner mental barbel length & 7.1 & $4.0-8.0$ & 6.6 & 1.2 \\
\hline Head length & 30.0 & $24.6-30.7$ & 28.1 & 1.6 \\
\hline \multicolumn{5}{|l|}{ Percents of head length } \\
\hline Head width & 59.3 & $44.9-63.9$ & 57.3 & 4.3 \\
\hline Head depth & 48.8 & $40.6-57.6$ & 47.2 & 4.3 \\
\hline Interorbital distance & 47.2 & $46.1-57.9$ & 50.2 & 3.9 \\
\hline Left internarial width & 16.5 & $12.8-21.2$ & 17.1 & 1.9 \\
\hline Anterior Internarial distance & 28.3 & $22.4-29.9$ & 26.7 & 2.2 \\
\hline Posterior internarial distance & 31.2 & $30.0-38.2$ & 33.3 & 2.4 \\
\hline Snout length & 29.5 & $27.9-38.5$ & 33.1 & 3.1 \\
\hline Orbital diameter & 28.3 & $21.1-32.7$ & 25.8 & 3.7 \\
\hline Mouth width & 37.4 & $37.4-50.5$ & 42.6 & 3.0 \\
\hline
\end{tabular}

broad slightly convex from snout tip to pectoral-fin insertion. In lateral view, dorsal profile of body from dorsal-fin base to caudal fin slightly to distinctly convex. Ventral profile of head and abdomen almost straight. Greatest body width at pectoral-fin origin. Ventral profile of body gently concave between anal-fin base and caudal-fin 
origin. Greatest body depth at origin of dorsal fin. Trunk from dorsal-fin base to caudal peduncle gradually compressed. Head integument thick, obscuring bones of cranial roof; adipose eyelid weakly developed; eye lateral on anterior portion of head; mouth terminal, upper lip extended posterolaterally, fleshy rictal fold well developed; snout margin rounded in dorsal view; anterior nostril tubular, located on anterior border of snout; posterior nostril somewhat larger, rounded, limited anteriorly by small skin flap; transverse distance between anterior nostrils slightly smaller than distance between posterior ones. Maxillary barbel elongate, reaching approximately vertical through middle of dorsal-fin or beyond; adpressed maxillary barbel fits in groove on the lateral portion of head, immediately above rictal fold and below eye; mental barbels very short, tips not reaching pectoral-fin base; bases of barbels arranged in arc along ventral surface of jaw; inner mental barbel about two-thirds length of outer mental (63.5-67.7\% in outer mental). Posterior process of cleithrum moderately large, almost reaching vertical through base of dorsal-fin spine. Coracoid process developed, about same length as pectoral-fin base.

Dorsal fin II,5; originated slightly posterior to vertical through origin of pectoral fin; spinelet rigid, triangular in frontal view, covered by thin layer of skin; dorsal-fin spine straight, strong, pungent, shorter than first branched ray, with filamentous tip; anterior margin of dorsal-fin spine with 9-15 denticulations, posterior margin smooth $(n=6)$; first branched ray longest, subsequent rays decreasing gradually in length; last dorsal-fin ray approximately half length of first branched ray; distal margin of dorsal fin rounded. Adipose fin absent. Pectoral fin I,5; pectoral spine, rigid, pungent, anterior margin with 15-19 denticulations, posterior margin with 11-15 denticulations $(n=6)$; pectoral-fin spine denticulations becoming progressively more prominent distally; first branched ray longest, subsequent rays decreasing in length; posterior margin of pectoral fin obliquely truncate. Pelvic fin i,5; origin at or slightly posterior to middle of body; first branched ray longest, subsequent rays decreasing in length; posterior pelvic-fin margin straight or slightly rounded. Anal fin ii-iii, $6(n=4)$ or ii-iii, $7(n=13)$; origin approximately on last third of standard length, posterior to vertical through tips of pelvic-fn rays; last ray unbranched, first and second branched rays longest; distal margin rounded. Caudal fin i, $15, i$; deeply forked, with approximately rounded lobes; dorsal and ventral caudal-fin lobes equal in length; outer principal rays unbranched, seven branched rays on dorsal lobe and eight branched rays on ventral lobe; 14-17 upper procurrent, 13-15 lower procurrent rays $(\mathrm{n}=3)$.

Rostral border of cranium with mesethmoid longer than broad; premaxilla with synchondral articulation; cranial fontanel narrow and elliptical, enclosed by mesethmoid and frontals (Fig. 2). Nasal ossified as short tubular bone situated between mesethmoid cornua and lateral ethmoid, not sutured to mesethmoid. Lateral ethmoid not participating in dorsal face of cephalic shield. Autopalatine rod-like, oriented almost parallel to longitudinal axis of body; maxilla slightly elongated, about twice the size of autopalatine; vomer arrow-shaped with short rostral-lateral processes. Jaws of equal size; premaxilla and dentary slender, each with two or three rows of robust conical teeth. Anterior nuchal plate absent; middle nuchal plate slightly concave along lateral margins; posterior nuchal plate short, projected laterally, with prominent tip. Epioccipital process very small (Fig. 2).

Hyomandibula broad, projected anteriorly, connected to both quadrate and 


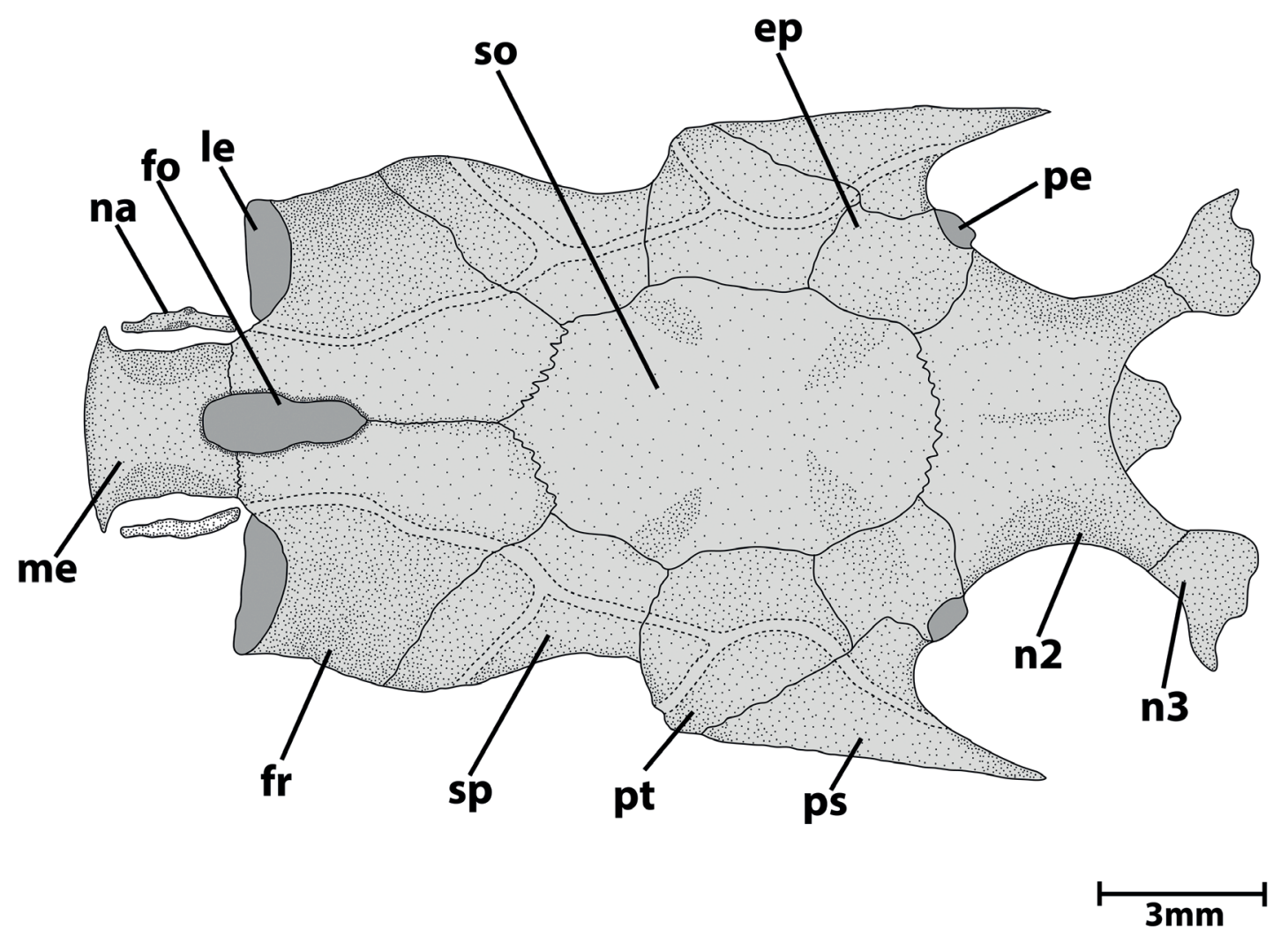

FIGURE 2 I Neurocranium of Tatia akroa, UFOPA-I 670, 34.3 mm SL. Dorsal view. Abbreviations: ep, epioccipital; fo, cranial fontanel; fr, frontal; le, lateral ethmoid; me, mesethmoid; na, nasal; n2, second nuchal plate; $\mathbf{n} 3$, third nuchal plate; pe, pterotic; ps, posttemporalsupracleitrum; pt, pterotic; so, supraoccipital; sp, sphenotic. Scale bar $=3 \mathrm{~mm}$. 


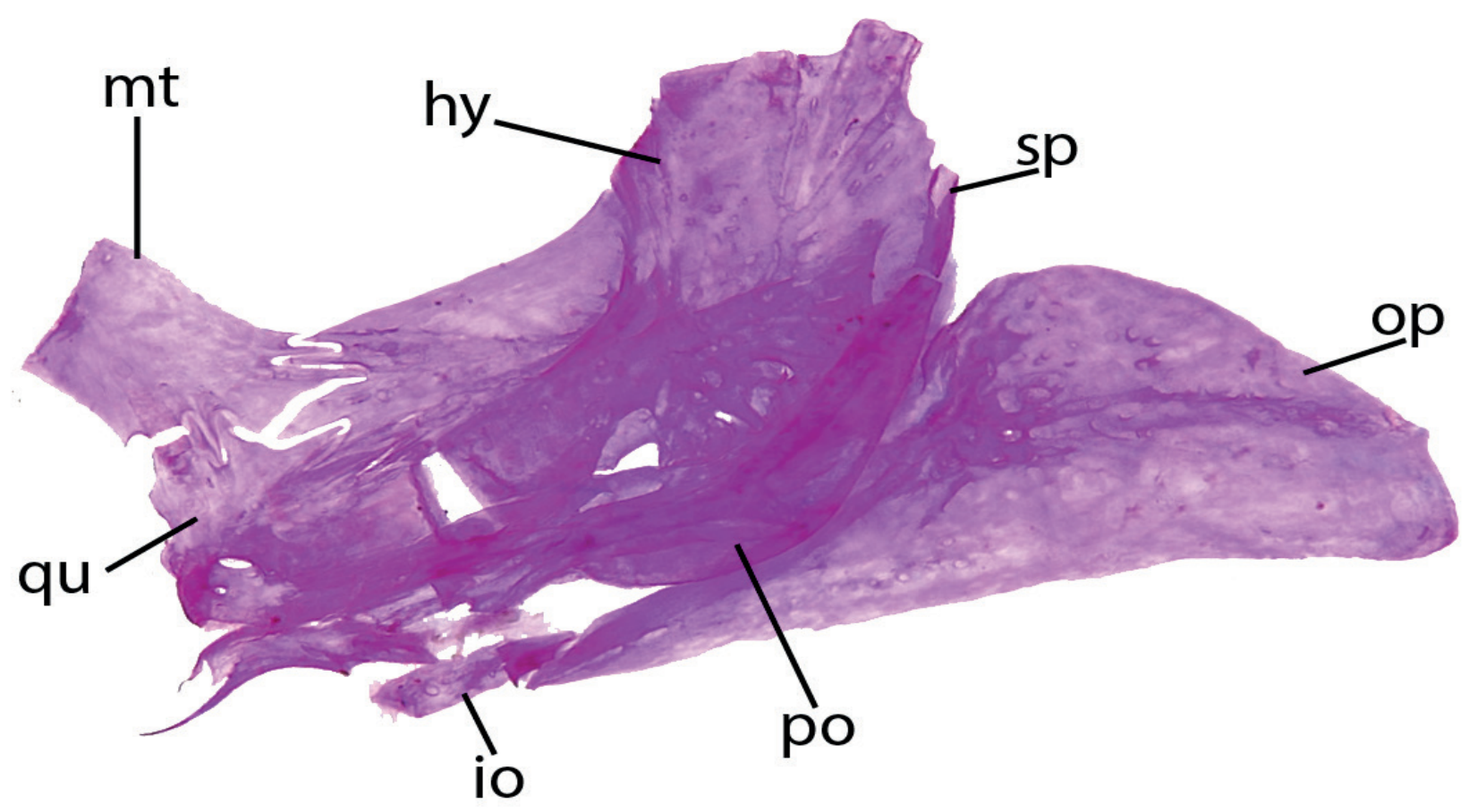

FIGURE 3 I Left suspensorium, lateral view, of Tatia akroa, UFOPA-I 670, 34.3 mm SL. Abbreviations: hy, hyomandibula; io, interopercle; mt, metapterygoid; op, opercle; po, preopercle; qu, quadrate; sp, suprapreopercle.

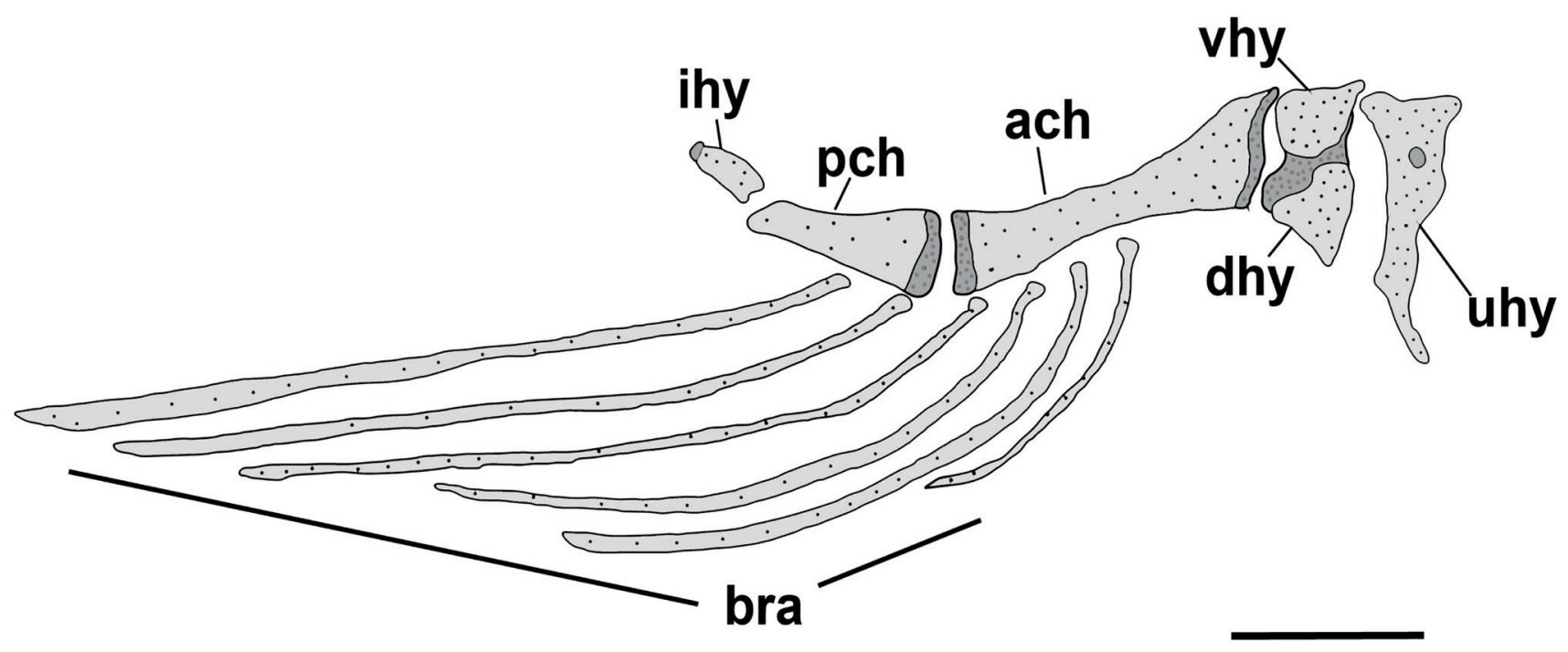

FIGURE 4 I Right hyoid arch of Tatia akroa, MZUSP 44071, 26.0 mm SL. Ventral view. Abbreviations: ach, anterior ceratohyal; bra, branchiostegal rays; dhy, dorsal hypohyal; ihy, interhyal; pch, posterior ceratohyal; vhy, ventral hypohyal; uhy, urohyal. Scale bar = 1 mm.

4 bordered laterally by cartilaginous head of ceratobranchial 4 and caudally by cartilaginous head of ceratobranchial 5 .

Hypobranchials 1 and 2 subtriangular, mostly osseous, elongate and expanded 
laterally, with cartilaginous tips; hypobranchial 3 completely cartilaginous, trapezoidal; hypobranchial 4 absent. Five ceratobranchials, mostly ossified, with cartilage on both ends. Ceratobranchials supporting single row of rakers; fifth ceratobranchial expanded postero-medially to support lower pharyngeal toothplate with short conical teeth. Four epibranchials, all largely ossified except for cartilaginous ends, supporting few rakers each, close to articulation with ceratobranchials. Epibranchials 1 and 2 rodlike; epibranchial 3 with posterior uncinate process in articulation to epibranchial 4; epibranchial 4 with laminar extension; reduced accessory cartilage, located on angle between cartilaginous ends of epibranchial 4 and ceratobranchial 4. Pharyngobranchial 1 absent; pharyngobranchial 2 short, cartilaginous, somewhat ellipsoid, placed between anteromedial cartilaginous tips of epibranchials 1 and 2; pharyngobranchial 3 elongate, ossified, with expanded posterior border; pharyngobranchial 4 ossified. Upper pharyngeal tooth plate bearing conical teeth, supported by pharyngobranchial 3 and 4 , and also epibranchials 3 and 4.

Infraorbital 1 with ventro-lateral process restricted to anterior border of eye, and followed by four canal-like bones, in incomplete infraorbital series. Lateral line on body straight, inconspicuous, with ossified canal bones only anteriorly, unbranched at caudal fin.

Ribs 8-9 attached to consecutive vertebrae 6-13, becoming progressively smaller posteriorly. Total vertebrae $35(\mathrm{~N}=4)$, observed in cleared and stained (CS) and radiographed specimens $(\mathrm{R})$.

Color in alcohol. Color light brown with dots, formed by chromatophores scattered on the head and mid-dorsal portions of body; sometimes dorsal surface of head and dorsolateral region darker along entire trunk, with more concentrated chromatophores from mid-dorsal region to lateral line. Sides of body with light brown chromatophores, becoming sparse ventrally. Fins almost hyaline; rays mottled with pale brown spots along base. Dorsal fin with a dark spot localized in proximal region. Caudal-fin base with irregular black to brown spots; fin becoming hyaline towards distal margin.

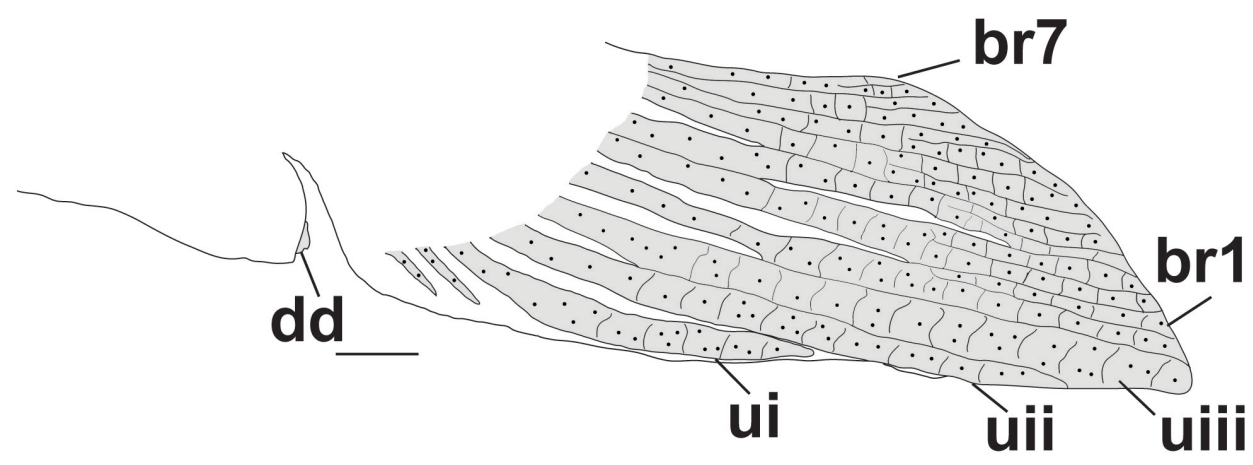

FIGURE 5 I Anal fin of Tatia akroa. UFOPA-I 671, male, 38.8 mm SL, holotype. Abbreviations: br1, branched ray one; br7, branched ray seven; dd, deferent duct; $\mathbf{u i}$, unbranched first ray; uii, unbranched second ray; uiii, unbranched third ray. Scale bar $=1 \mathrm{~mm}$. 


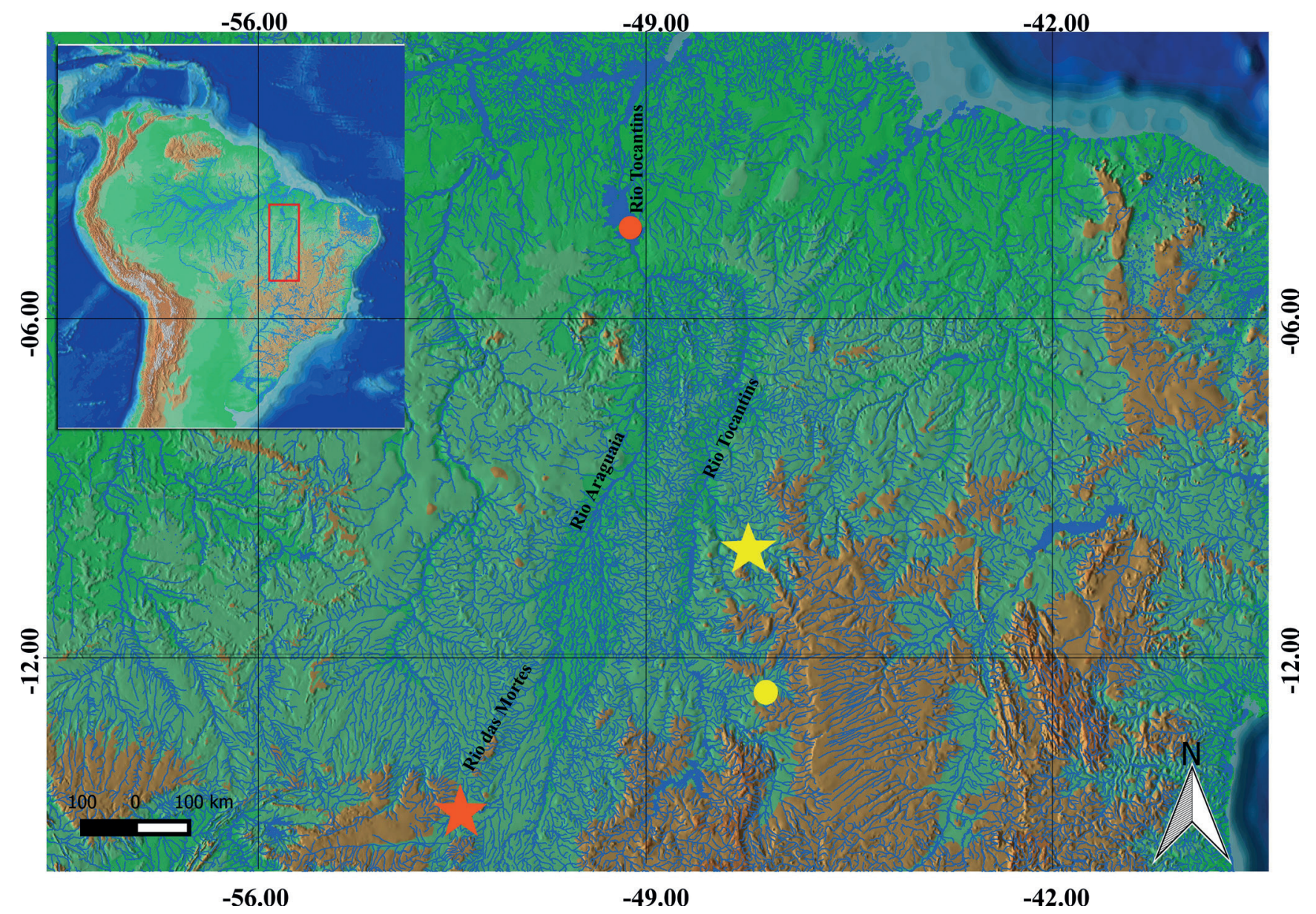

FIGURE 6 I Distribution of Tatia akroa (yellow) and T. simplex (orange). Stars represent type localities.

Sexual dimorphism. Observed in one male with partially modified anal fin for insemination (Figs. 1, 5). Five first proximal radials closely together, not fused, with sutures visible. Last three proximal radials elements arranged as in non-breeding and females (according previous descriptions for congeners). Unbranched and first branched anal-fin rays fused together to form a structure for insemination at anterior portion of the anal fin. Urogenital opening at base of anal fin as simple pore at the distal tip of a tubular structure bound by integument. Deferent duct externally visible as a genital papilla.

Distribution. Tatia akroa is known from the upper portion of the rio Tocantins drainage (Fig. 6).

Ecological notes. One of the specimens examined was dissected and its stomach contained fragments of terrestrial insects including Diptera and Coleoptera.

Conservation status. Tatia akroa is known from the rio Perdida and rio Palma, upper rio Tocantins drainage. Considering its Extent of Occurrence (EOO) and that no major 
threats to the species were detected in the area of distribution we suggest that $T$. akroa should be categorized as least concern (LC) according to the International Union for Conservation of Nature categories and criteria (IUCN, 2019).

Etymology. The specific name is a reference to the Akroa indigenous people, inhabitants of lands from eastern Tocantins to southern Piauí until the XIX century (Apolinário, 2005). The Akroá lived along valleys on Serra Geral do Tocantins, a watershed divide between the right margin of rio Tocantins and rio Parnaíba upper valleys respectively. Their territory included the rio Manuel Alves sub-basin of rio Tocantins, distribution range of the new Tatia species. A noun in apposition.

\section{DISCUSSION}

The parieto-supraoccipital joined to middle nuchal plate, with resultant absence of an anterior nuchal plate, is a condition shared by Tatia akroa and ten species presently assigned under Tatia, namely: T. bockmanni, T. britskii, T. concolor, T. marthae, T. melanoleuca, T. musaica, T. orca, T. punctata, T. reticulata, and T. simplex. In addition, the lack of anterior nuchal plate is shared by a few Centromochlinae species (Balroglanis carolae, B. macracanthus, B. schultzi, Duringlanis romani, Ferrarissoaresia ferrarisi, and F. meridionalis) and by all Gelanoglanis species (G. stroudi, G. nanonocticolus, G. travieso, and G. pan). Among the species of Tatia a parieto-supraoccipital joined to anterior nuchal plate is shared by Tatia aulopygia, T. boemia, T. brunnea, T. caudosignata, T. caxiuanensis, T. caudosignata, T. dunni T. galaxias, T. grrina, T. jaracatia, T. intermedia, T. meesi, T. neivai, T. nigra, and T. strigata.

Among the centromochlins lacking an anterior nuchal plate, a restricted group of Tatia species composed by Tatia akroa, T. bockmanni, T. britskii, T. concolor, T. marthae, T. punctata, and T. simplex are morphologically very similar. Besides the arrangement of cranial nuchal plates, a modified anal fin of mature males with reduced posterior rays, bearing one or two (sixth and/or seventh branched rays) smaller or rudimentary; and also a similar color pattern, with scattered dots over a pale body and translucent fins, with the exception of T. punctata, which specimens exhibits a vermiculated color pattern. Most of these species were originally described in Tatia, however remained for a long time under Centromochlus (i.e. Tatia concolor, T. simplex, and T. punctata), or Glanidium (Tatia bockmanni), and some (i.e. Tatia britskii) were originally described under Centromochlus, and now placed under Tatia (Calegari et al., 2019). The difficulties in solving relationships of some of these species within Tatia are that only type material is available, with few specimens in collections. The few specimens available in fish collections make accurate identification of these species difficult, and some names as Tatia simplex and also T. marthae, were based upon juveniles specimens only.

Tatia simplex was described as having an extremely small adipose fin, smaller than other centromochlins species (Mees, 1974: 93). Although the significance of reduced adipose fin in the holotype was stated as uncertain regarding the diagnosis of the species, additional specimens with a reduced adipose fin were found in rio Tocantins drainage. Analysis of these specimens support the hypothesis that T. simplex is distinguished from all Centromochlinae by the adipose-fin base length corresponding to $1.5 \%$ or less 
in SL ( $v s$. adipose-fin base length more than $2 \%$ in SL, even in species with adipose fin proportionally smaller, as Centromochlus existimatus and C. heckelii). Tatia simplex is further distinguished from C. existimatus and C. heckelii by lacking anterior nuchal plate ( $v$ s. anterior nuchal plate present) and shorter pectoral-fin spine (20.7-22.7\% of SL vs. 29.3-41.6\% of SL). Tatia simplex differs from T. akroa and T. britskii, the only species lacking an adipose fin, by the posterior border of dorsal-fin spine with 1 to 3 distal denticulations ( $v s$. smooth margin). Among species of Centromochlinae that share the absence of anterior nuchal plate (i.e. Balroglanis macracanthus, B. schultzi, Duringlanis romani, Ferrarissoaresia meridionalis, T. bockmanni, T. concolor, T. punctata, $T$. reticulata, and T. simplex), Tatia simplex differs from both Balroglanis macracanthus and $B$. schultzi by having posterior margin of dorsal-fin spine smooth ( $v s$. denticulated); differs from T. punctata and T. concolor by irregular or retrorse orientation of dentations along anterior margin of pectoral-fin spine ( $v s$. regularly spaced antrorse dentations); and by the morphology of male modified anal fin, specifically, the last branched anal-fin ray progressively shorter than anterior most ( $v s$. last ray abruptly reduced, size half that of preceding one and visible only through dissection).

Tatia simplex was originally described from rio das Mortes, tributary of left margin of rio Araguaia, on Mato Grosso State, Brazil. This species is scarcely represented in scientific collections. The revision of distribution patterns based on additional material of $T$. simplex suggests that the species is restricted to the Tocantins-Araguaia system, with records from rio das Mortes and lower rio Tocantins (Fig. 7).

Comparative material examined. Ferrarissoaresia meridionalis. Brazil. Mato Grosso State. INPA 37897, 2 CS, paratypes of Centromochlus meridionalis Sarmento-Soares et al., 2013, 29.7-39.2 mm SL, MBML 5616, 1 CS, paratype of Centromochlus meridionalis Sarmento-Soares et al., 2013, $39.1 \mathrm{~mm} \mathrm{SL}$, and MNRJ 40702, 3, paratypes of Centromochlus meridionalis Sarmento-Soares et al., 2013, 32.6-38.3 mm SL, córrego Loanda, a small tributary of rio Roquete, Cláudia. Ferrarissoaresia ferrarisi. Brazil. Tocantins State. MNRJ 41924, 1, paratype of Centromochlus ferrarisi Birindelli et al., 2015, $57.6 \mathrm{~mm} \mathrm{SL}$ and MZUSP 115352, 2, 1 CS, paratypes of Centromochlus ferrarisi Birindelli et al., 2015,

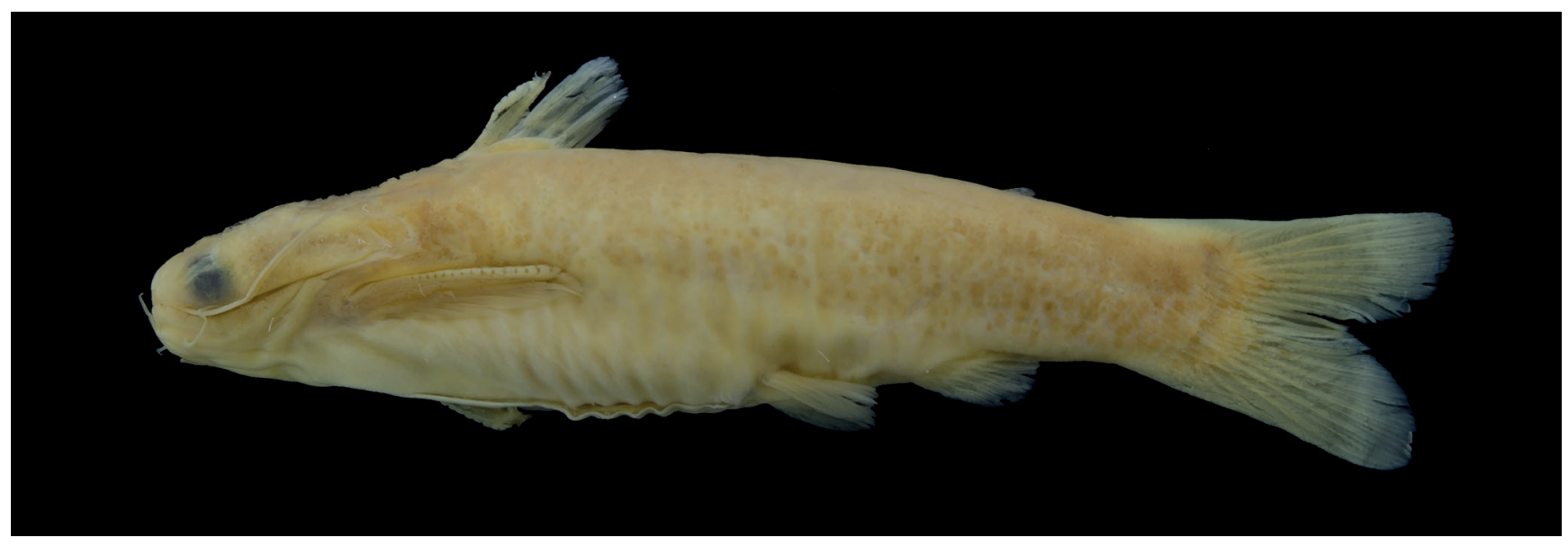

FIGURE 7 I Lateral view of Tatia simplex, MZUSP 44071, $48.3 \mathrm{~mm}$ SL, rio Tocantins on Jatobal falls. 
50.4-68.1 mm SL, rio da Conceição, headwater of rio das Balsas, Estação Ecológica Serra Geral do Tocantins. Centromochlus existimatus. Brazil. Pará State. INPA 40662, 6, 46.5-59.0 mm SL, public beach, right margin of rio Xingu, Porto de Moz. Centromochlus heckelii. Brazil. Amapá State. MNRJ 12130, 8, 33.4-61.8 mm SL, Fazendinha, rio Amazonas, near Macapá. Pará State. MZUSP 8336, 2 CS, 53,4- 62,0 mm SL, rio Tapajós, Santarém. Duringlanis altae. Colombia. USNM 121965, 1, 35.5 mm SL, río Dedo, tributary of río Orteguazo. Duringlanis perugiae. Ecuador. ANSP 130611, 14, 30.1-45 mm SL, rio Aguarico in Santa Cecilia, Napo. FMNH 92005, 1 CS, río Rutun Celutu. Duringlanis romani. Venezuela. MCNG 14896, 18, 29.0 mm SL, río San Jose, Guanare. RMNH.PIS 30491, 3, Rx, paratypes, 27.1-31.3 mm SL, Monagas, Maturin. Balroglanis macracanthus. Brazil. Amazonas State. MZUSP 30605, 2, 65.7-71.8 mm SL, paratypes, rio Negro, cachoeira de São Gabriel, São Gabriel da Cachoeira. Balroglanis schultzi. Brazil. Goiás State. MNRJ 12139, 38, 1 CS, 85.0-108.9 mm SL, Serra da Mesa dam, upper rio Tocantins. Balroglanis carolae. Guyana. ANSP 175836, 9, 22.3-30.5 mm SL. MNRJ 30491, 1, CS, 23.7 mm SL, Essequibo River. USNM 401511, 1, Rx, 31.9 mm SL, paratype of T. carolae Vari, Ferraris, 2013, Cuyuni River, sand and gravel beaches downstream from rapids at Kanaima Falls, Cuyuni- Mazaruni. USNM 401514, 1, Rx, $37.2 \mathrm{~mm}$ SL, holotype of of T. carolae Vari, Ferraris, 2013, Cuyuni River, sand island in middle of river just downstream from Kurutuku, Essequibo River basin, CuyuniMazaruni. Tatia aulopygia. Brazil. Amazonas State. ZMA.PIS 114.280, 2, Rx, 39.6-46.8 mm SL; Humaitá, Madeira River drainage. Rondônia State. INPA 11078, 1, 76.2 mm SL, INPA 11079, 1, $159.0 \mathrm{~mm}$ SL and INPA 11080, 3, 1 CS, 80.0-104.6 mm SL; Guaporé River. Tatia bockmanni. Brazil. Bahia State. MZUSP 82351, 8, 1 CS, paratypes of Glanidium Bockmanni Sarmento-Soares, Buckup, 2005, 29.4-35.8 mm SL, rio Preto at Formosa do rio Preto. Tatia britskii. Brazil. São Paulo State. MZUSP 43251, 2, 1 CS, 33.5-36.3 mm SL, paratypes of Centromochlus britskii Sarmento-Soares, Birindelli, 2015, and MNRJ 41787, 2, 36.0-38.6 mm SL, paratypes of Centromochlus britskii SarmentoSoares, Birindelli, 2015, rio Paraná where is now the Ilha Solteira reservoir, upper rio Paraná basin. Tatia boemia. Brazil. Rio Grande do Sul State. MCP 12949, 6, 1 CS, paratype, 33.1-61.1 mm SL; and MZUSP 47921, 2, Rx, paratypes, 52.4-64.5 mm SL; Pelotas River on road Anita Garibaldi to Pinhal da Serra, Esmeralda. Tatia brunnea. Brazil. Amazonas State. INPA 14228, 2, 96.9-97.4 mm SL, Urubu River, igarapé of Gavião, Farm Esteio, Negro River basin. INPA 29988, 4, 17.9-42.4 mm SL, Preto da Eva River, Cabo Frio, Manaus. MZUSP 31075, 1, 34.0 mm SL, Negro River, island lake, Barcelos. Tatia caxiuanensis. Brazil. Pará State. MPEG 6201, 7, 1 CS, paratypes, 29.3-40.7 mm SL, and MNRJ 28821, 2, paratypes, 31.3-35.3 mm SL, Estação Científica Ferreira Pena, Curuá River, Caxiuanã, Melgaço. Tatia caudosignata. Colombia. Amazonas Department. IAvH-P 8932, 2, 1 CS, 91.4 - 101.3 mm SL, quebrada Sufragio, in front of the Reserva Biológica El Zafire, Leticia. IAvH-P 9394, 3, 67.3- $123.7 \mathrm{~mm}$ SL; 1 CS, tributary stream to the río Pureté, 3 hours from Salado Varios, Parque Nacional Natural Amacayacu, Leticia. Tatia concolor. Suriname. ZMA 106210, 1, 33.4 mm SL, holotype of T. concolor Mees, 1974, Rx, ZMA 106209, 29.0-30.6 mm SL, paratype of T. concolor Mees, 1974, Rx, Coppename River. Tatia dunni. Brazil. Amazonas State. INPA 3017, 1, 69.0 mm SL, Igarapé Madalena, Catalão, Solimões River. INPA 18477, 3, 72.0 $87.8 \mathrm{~mm}$ SL, Tupinambaranas Island. Tatia galaxias. Venezuela. CAS 6568, 4, paratypes, 49.0-56.6 mm SL, and RMNH.PIS 26493, 2, Rx, paratypes, 48.5-55.6 mm SL, 
Quiribana stream, near Caicara, Orinoco basin. AMNH 91381, 1, 125.6 mm SL, Mavaca River. Tatia gyrina. Brazil. Amazonas State. MCZ 8182, 1, 32.7 mm SL, Solimões River in Codajás. INPA 18478, 1, 38.2 mm SL, Tefé. INPA 20970, 2, 29.0-36.2 mm SL, igarapé Branco, Reserva de Desenvolvimento Sustentável Amanã, Tefé. Tatia jaracatia. Brazil. Paraná State. MNRJ 31909, 1, paratype, 42.9 mm SL, lower Iguaçu River, Capitão Leônidas Marques. MNRJ 31910, 1, paratype, 57.0 mm SL, Jaracatiá River, Salto do Lontra. Tatia intermedia. Brazil. Amapá State. MNRJ 12132, 1, 66.0 mm SL, Maruanum River, tributary of Matapi River, Macapá. MNRJ 12133, 1, 31.9 mm SL, and MNRJ 12134, 9, 40.2-65.1 mm SL, Aporema River in Fazenda Modelo do Aporema, tributary of Araguari River. Tatia meesi. Guyana. INHS 99772, holotype, $44.3 \mathrm{~mm}$ SL, INHS 49549, 9, 1 CS, 30.3-46.6 mm SL, and MBML 2046, 3, 32.2-42.6 mm SL, Waratuk cataract, Essequibo River Drainage, lower Potaro River, Potaro-Siparuni. Tatia neivai. Brazil. Mato Grosso do Sul State. MZUSP 35882, 1, 26.6 mm SL, Piquiri River, Santo Antônio do Paraíso farm, Itiquira. MZUSP 36364, 2, 27.7-46.8 mm SL, Corixão, Capão Grande, Nhecolândia, Corumbá. Tatia nigra. Brazil. Amazonas State. INPA 11081, 6, paratypes, 86.6-107.8 mm SL, and MNRJ 32024, 2, 1 CS, paratypes, 97.0-98.2 mm SL, Uatumã River, Samaúma lake, Presidente Figueiredo. INPA 43876, 2, 100.5 -106.6 mm SL, Nhamundá River below Sete Ilhas Lake. Tatia marthae. Venezuela. ANSP 146201, 1, Rx, 23.1 mm SL, holotype of T. marthae Vari, Ferraris, 2013, Bolivar, cãno Cuchima of río Cusimi, approximately 20 mi upstream from junction of río Erebato at Entre Ríos; ANSP 199070, 1, Rx, $19.0 \mathrm{~mm}$ SL, paratype of T. marthae Vari, Ferraris, 2013, collected with holotype. Tatia melanoleuca. Brazil. Pará State. MZUSP 8535, 6, 1 CS, 46.9-76.5 mm SL, rio Tapajós, Santarém. MZUSP 30585, 6, 1CS, 35.048.4 mm SL, rio Tapajós, Alter do Chão. Tatia musaica. Venezuela. AMNH 58795, 3, 25.1-29.0 mm SL, paratypes of T. musaica Royero, 1992, MBUCV-V 15663, $47.1 \mathrm{~mm}$ SL, holotype. ANSP 160656, 1, $57.0 \mathrm{~mm}$ SL, rio Sipapo, above Pendare. MBUC-V 17727, 1, paratype of T. musaica Royero, 1992, $26.8 \mathrm{~mm}$ SL, rio Atabapo, approximately $3 \mathrm{~km}$ from its mouth, San Fernando de Atabapo. MCNG 21796, 1, $50.8 \mathrm{~mm}$ SL, caño La Chimita 3-15 km above confluence with rio Atacavi. Brazil. Roraima State. MZUSP 9347, 1, 29.4 mm SL, rio Uraricoera, Maracá island, near Fazenda Canadá. Tatia orca. Brazil. Pará State. INPA 35086, 14 +1 CS, 40.5-56.8 mm SL, MBML 11221, 1 CS, 50.6 mm SL, MNRJ 45072, 5, 1 CS, 38.2-52.3 mm SL, mouth of Igarapé Jamari with lago de Terra Santa, rio Nhamundá basin, Terra Santa. Tatia punctata. Brazil. Pará State. MNRJ 9417, 2, 32.7-60.8 mm SL, upper rio Xingu. RMNH.PIS 26494, 2, Rx, paratypes of T. punctata Mees, 1974, 33.3-43.2 mm SL, Igarapé Kumadueni, tributary of rio Paru. Suriname. RMNH.PIS 26495, $45.0 \mathrm{~mm}$ SL, holotype of Tatia punctata Mees, 1974 and RMNH.PIS 26496, 3, 36.2-39.3 mm SL, Rx, paratypes of T. punctata Mees, 1974, rivers between Kabel and Lombé. Tatia reticulata. Brazil. Amazonas State. INPA 35394, 6, 18.3-28.8 mm SL, rio Tapauá, indigenous land Paumari do Cuniuá, rio Purus. Colombia. ANSP 128797, 4, 30.7-34.2 mm SL, Caño Emma, Finca El Viento, ca. 33.5 km NE Puerto Lopez. Meta. MNRJ 30492, 1, CS, 30.8 mm SL, Cano Emma, Finca El Viento, ca. 33.5 km NE Puerto Lopez. Meta. Guyana. RMNH.PIS 26744, 2, Rx, 18.3$39.8 \mathrm{~mm}$ SL, paratypes of T. reticulata Mess, 1974, Karanambo, Rupununi. Colombia. Tatia simplex. Brazil. Mato Grosso State. BMNH 1971.7.29.5, 1, 28.5 mm SL, holotype of T. simplex Mees, 1974, rio das Mortes, Araguaia drainage. Tocantins State. INPA 18475, 1, 19.9 mm SL, Jatobal rapids, Araguacema. MZUSP 44071, 2, 26.0-49.3 mm 
SL, 1 CS, lagoon in front of Jatobal, rio Tocantins, Araguacema. MZUSP 44074, 1, 26.5 mm SL, lake near Capitariquara channel, near Jatobal, Araguacema. Tatia strigata. Brazil. Amazonas. MZUSP 7357, 35, paratypes, 20.5-38.6 mm SL, Maués, Igarapé Limãozinho. MZUSP 7298, 23, paratypes, 16.3-31.2 mm SL, and MZUSP 44066, 2 CS, paratypes, 37.0-38.9 mm SL, Igarapé of Marau River, Maués. Tatia sp. Brazil. Pará State. MZUSP 111840, 43.8 mm SL, rio Xingu. MZUSP 36862, 1 CS, 28.4 mm SL, rio Xingu.

\section{ACKNOWLEDGMENTS}

We thank Lúcia R. Py-Daniel (INPA), Aléssio Datovo, Osvaldo Oyakawa and Michel Gianeti (MZUSP), Carlos do Nascimento (IAvH-P) and Paulo Lucinda (UNT) for curatorial assistance. We are indebted to C.J. Ferraris and J.L.O. Birindelli (MZUEL), for further comments and suggestions on manuscript draft. JSS thanks the Fundação Amazônia de Amparo a Estudos e Pesquisa (FAPESPA) for the fellowship granted (ICAAF \#056/2016). ALCC and FRVR were partly supported by CNPq (ICAAF \#436763/2018-4) and Programa de Fortalecimento dos Grupos de Pesquisa/UFOPA. We are indebted to Instituto Nossos Riachos (INR) database for images of some specimens in present study.

\section{REFERENCES}

- Akama A, Sarmento-Soares LM. Família Auchenipteridae. In: Buckup PA, Menezes NA, Ghazzi MS, editors. Catálogo das espécies de peixes de água doce do Brasil. Rio de Janeiro: Museu Nacional; 2007. p.116-20.

- Apolinário JR. Os Akroá e outros povos indígenas nas Fronteiras do SertãoAs práticas das políticas indígena e indigenistas no norte da capitania de Goiás - Século XVIII. [PhD Thesis]. Recife: Universidade Federal de Pernambuco; 2005. Available from: https://repositorio. ufpe.br/bitstream/123456789/7522/1/ arquivo7826_1.pdf

- Birindelli JLO. Phylogenetic relationships of the South American Doradoidea (Ostariophysi: Siluriformes). Neotrop Ichthyol. 2014; 12(3): 451-564. http://dx.doi. org/10.1590/1982-0224-20120027

- Birindelli JLO, Sarmento-Soares LM, Lima FCT. A new species of Centromochlus (Siluriformes, Auchenipteridae, Centromochlinae) from the middle rio Tocantins basin, Brazil. J Fish Biol. 2015; 87:860-75. https://doi.org/10.1111/jfb.12750
- Calegari BB, Vari RP, Reis RE. Phylogenetic systematics of the driftwood catfishes (Siluriformes: Auchenipteridae): a combined morphological and molecular analysis. Zool J Linn Soc. 2019; 187:661773. https://doi.org/10.1093/zoolinnean/ zlz036

- Dahdul WM., Lundberg JG, Midford PE, Balhoff JP, Lapp H, Vision TJ, Haendel MA, M. Westerfield M, Mabee PM. The Teleost Anatomy Ontology: Anatomical Representation for the Genomics Age. Syst Biol. 2010; 59: 369-383. https://doi. org/10.1093/sysbio/syq013

- Ferraris CJ, Jr. Family Auchenipteridae. In: Reis RE, Kullander SO, Ferraris CJ, Jr., editors. Check list of the freshwater fishes of South and Central America. Porto Alegre: Edipucrs; 2003. p.470-82. https:// doi.org/10.1643/OT-04-142

- Ferraris CJ, Jr. Checklist of catfishes, recent and fossil (Osteichthyes: Siluriformes), and catalogue of siluriform primary types. Zootaxa. 2007; 1418:1-628. http://dx.doi.org/10.11646/ zootaxa.1418.1.1 
- International Union for Conservation of Nature (IUCN). Standards and Petitions Subcommittee. Guidelines for using the IUCN Red List categories and criteria. Version 14 [Internet]. Gland; 2019. DOI: $10.1002 / j o c .3480$. Available from: http://www.iucnredlist.org/documents/ RedListGuidelines.pdf

- Mees GF. The Auchenipteridae and Pimelodidae of Suriname (Pisces, Nematognathi). Zoologische Verhandelingen. 1974; 132:1-256.

- Sabaj Pérez MH. Standard symbolic codes for institutional resource collections in herpetology and ichthyology: an Online Reference. Verson 3.0 (23 February 2012). Electronically accessible at http:// www.asih.org/, American Society of Ichthyologists and Herpetologists, Washington, DC. 2012.

- Sarmento-Soares LM, Buckup PA. A new Glanidium from the rio São Francisco basin, Brazil (Siluriformes: Auchenipteridae: Centromochlinae). Copeia. 2005(4); 846-53. https://doi. org/10.1643/0045-8511(2005)005[0846:ANG FTR]2.0.CO;2

- Sarmento-Soares LM, Birindelli JLO. A new species of the catfish genus Centromochlus (Siluriformes: Auchenipteridae: Centromochlinae) from the upper rio Paraná basin, Brazil. Neotrop Ichthyol. 2015; 13(1):77-86. http://dx.doi. org/10.1590/1982-0224-20140042
- Sarmento-Soares LM, MartinsPinheiro RF. A systematic review of the Tatia (Siluriformes: Auchenipteridae: Centromochlinae). Neotrop Ichthyol. 2008; 6(3):495-542. http://dx.doi.org/10.1590/ S1679-62252008000300022

- Soares-Porto LM. Monophyly and interrelationships of the Centromochlinae (Siluriformes: Auchenipteridae). In: Malabarba LR, Reis RE, Vari RP, Lucena ZMS, Lucena CAS, editors. Phylogeny and Classification of Neotropical Fishes. Porto Alegre: Edipucrs; 1998. p.331-50.

- Taylor WR, Van Dyke GC. Revised procedures for staining and clearing small fishes and other vertebrates for bone and cartilage study. Cybium. 1985; 9(2):107-19. Available from: http://sfi-cybium.fr/en/ node/2423

- Vanscoy T, Lundberg JG, Luckenbill KR. Bony ornamentation of the catfish pectoral-fin spine: comparative and developmental anatomy, with an example of fin-spine diversity using the tribe Brachyplatystomini (Siluriformes, Pimelodidae). Proc Acad Nat Sci Philadelphia. 2015; 164(1):177-212. https:// doi.org/10.1635/053.164.0107

- Vari RP, Ferraris CJ, Jr. Two new species of the catfsh genus Tatia (Siluriformes: Auchenipteridae) from the Guiana Shield and a reevaluation of the limits of the genus. Copeia. 2013(3); 396-402. https://doi. org/10.1643/CI-12-115

\section{AUTHOR CONTRIBUTIONS}

Jordson de Souza e Souza: Conceptualization, Data curation, Formal Analysis, Investigation, Methodology, Resources, Visualization, Writing (original draft).

Luisa M. Sarmento-Soares: Conceptualization, Data curation, Formal Analysis, Funding acquisition, Investigation, Methodology, Project administration, Resources, Supervision, Validation, Visualization, Writing (original draft), Writing (review \& editing).

André L. Colares Canto: Data curation, Formal Analysis, Investigation, Methodology, Software, Visualization, Writing (original draft).

Frank Raynner V. Ribeiro: Conceptualization, Data curation, Formal Analysis, Funding acquisition, Investigation, Methodology, Project administration, Resources, Supervision, Validation, Visualization, Writing (original draft), Writing (review \& editing).

\section{ETHICAL STATEMENTS}

Not applicable. 


\section{Neotropical Ichthyology}

$$
\text { OPEN } \partial \text { ACCESS }
$$

\section{(c) (1)}

This is an open access article under the terms of the reprolicion in way mer use, distribution and reproduction in any medium

Distributed under

Creative Commons CC-BY 4.0

๑ 2020 The Authors.

Diversity and Distributions Published by SB

\footnotetext{
Official Journal of the

SBI

Sociedade Brasileira de Ictiologia
}

\section{COMPETING INTERESTS}

Not applicable.

\section{HOW TO CITE THIS ARTICLE}

- Souza SJ, Sarmento-Soares LM, Canto ALC, Ribeiro FRV. Description of a new species of Tatia from rio Tocantins drainage, central Brazil, with notes on Tatia simplex Mees, 1974 (Siluriformes, Auchenipteridae). Neotrop Ichthyol. 2020; 18(1):e190111. https://doi. org/10.1590/1982-0224-2019-0111 